\title{
Problémy Aplikace Metody Časného Zapojení ZHOTOVITELE
}

\section{Problems Of the EARLY CONTRACTOR INVOLVEMENT'S APPLICATION}

\author{
Radan Tomek ${ }^{* 1}$ \\ ${ }^{1}$ Czech Technical University in Prague, Faculty of Civil Engineering, Thakurova 7, Prague 6, 166 29, \\ Czech Republic, radan.tomek@fsv.cvut.cz, +420 224354817
}

\begin{abstract}
Abstrakt - CZ
Přes veškeré již dostatečně všeobecně známé výhody metody časného zapojení hlavního zhotovitele (tzv. Early Contractor Involvement), či v případě potřeby i vybraných subdodavatelů, je většina projektů i nadále dodávána pomocí jednostupňového výběru dodavatelů na základě stavebních smluv, jimiž se ř́dí pouze fáze výstavby. Jeví se proto jako zajímavé a důležité zjistit, proč se tak i přes prokazatelné výhody časného zapojení dodavatele do procesu př́pravy projektu děje a proč klienti s dodavateli smlouvy o předvýstavbové fázi projektu používají pouze v minoritním podílu projektů. Tento článek se zabývá možnými překážkami využívání smluv ve předvýstavbové fázi, a jejich specifiky pro určitý typ projektu co se týče jeho velikosti, složitosti či typu dodavatelského systému, kterým je realizován. Článek se zároveň zaměřuje na překážky plynoucí z problematiky osobních postojů účastníků projektu vůči metodě časného zapojení dodavatele, které s výše položenou otázkou, proč je tato metoda stále ve vztahu ke svým výhodám relativně tak málo rozšířena, úzce souvisí.
\end{abstract}

\section{Klíčová slova - CZ}

Design and build, dodavatelský systém projektu, early contractor involvement, předvýstavbová fáze projektu, časné zapojení zhotovitele

\section{Abstract - EN}

In spite of all the already well-known benefits of Early Contractor Involvement, or, if necessary, selected subcontractors, most projects continue to be delivered through a one-stage selection of suppliers based on construction contracts that govern only the construction phase. Therefore, it is interesting and important to find out why - despite the obvious benefits of early involvement of the contractor in the project preparation process - the clients cooperate with contractors during the preconstruction phase of the project so rarely. This article discusses possible barriers to the use of such contracted cooperation in the pre-construction phase and their specifics for a particular type of project in terms of its size, complexity or type of supply system to be implemented. At the same time, the article focuses on the obstacles arising from the personal attitudes of the participants of the project towards the method of early involvement of the supplier, which, with the above question, why this method is still not that widespread in relation to its advantages, is closely related.

\section{Keywords - EN}

Design and build, early contractor involvement, pre-construction phase, project delivery scheme 


\section{JEL Classification}

L74, L78

DOI: https://doi.org/10.14311/bit.2018.02.04

Editorial information: journal Business \& IT, ISSN 2570-7434, CreativeCommons license (c) (i) published by CTU in Prague, 2018, http://bit.fsv.cvut.cz/

\section{Rozměr a složitost projektu}

Využití potenciálu procesů uskutečnitelných $v$ předvýstavbové fázi projektu může být omezeno následujícími okolnostmi. Zejména velikost nebo jednoduchost projektu obecně může být důvodem věnování nižší pozornosti, či př́imo zanedbání procesům přípravné fáze projektu. Stejně tak klient nemusí být schopen, či dokonce ochoten nebo těmto procesům věnovat dostatek času. Toto se děje zejména $v$ prípadě, že klient nemá žádnou zkušenost z předchozích projektů, nebo pokud jsou tyto mimo či nad rámec odbornosti klienta.

U malých nebo jednoduchých projektů je možné, že architekt nebo inženýr dokončí veškeré projektové práce ještě před uskutečněním vyzvání $k$ podání nabídky od potenciálních hlavních dodavatelů. $V$ těchto prípadech bude prostor pro společnou práci mezi klientem, konzultanty a vybraným hlavním dodavatelem během předvýstavbové fáze výstavby pravděpodobně zanedbatelný. Tam, kde k předvýstavbové spolupráci mezi všemi stranami přeci jen dojde, jejich trvání bude nejspiše krátké a takové výměny názorů a zkušeností nebudou, co se týče jejich formy, pravděpodobně nijak formalizovány.

\section{Projekty typu design and build}

$\checkmark$ jiných projektech, a to bez ohledu na jejich velikost, má klient jednoduchou možnost pouze uvést své požadavky na parametry / výkon výsledné podoby projektu a nehrát v něm pak žádnou další roli. Pouze za splnění těchto požadavků uhradit pevně stanovenou cenu (tzv. fixed price) hlavnímu dodavateli. Takový klient bude očekávat, že předá odpovědnost za veškeré záležitosti a aktivity projektové i stavební činnosti hlavnímu dodavateli, a je pravděpodobné, že si zároveň bude prát zachovat kněmu i celkově vzato odstup, tzn že nechá hlavního dodavatele absolvovat jak předrealizační, tak i a realizační fázi projektu víceméně samostatně.

$\checkmark$ dodavatelském schématu design and build (DB) je klientova role největší v prvopočátku projektu, kdy musí jasně a srozumitelně definovat a zadat hlavnímu dodavateli své požadavky na jeho výsledek. Ten pak následně za účelem zajištění plnění cílů projektu v rámci požadovaných nákladů, časových a kvalitativních parametrů postupuje vlastními metodami a jeho možnostem nejvíce vyhovujícími prostředky a získává oproti ostatním dodavatelským systémům vysokou míru samostatnosti. Klient pak má o průběžném postupu nebo problémech vzniklých v průběhu trvání projektu málo informací a do projektu se nezapojuje. Děje se tak pouze $v$ př́padě, že $z$ průběhu realizace vyplynou změny, které budou mít vliv - at' už pozitivní či negativní - na výslednou podobu projektu či snad dokud se prípadné problémy vyloženě nestupňují až na úroveň formálního sporu.

Jak bylo právě popsáno, klient se v projektech typu design and build sice př́mo víceméně sám aktivně neangažuje, avšak že by projekty probíhaly zcela v samostatné režii hlavního dodavatele ríci nelze. Ve většině projektů působí totiž na straně klienta jím najatý dozor, resp. projektový manažer, který 
profesionálním způsobem kontrolu dodavatele jménem klienta vlastně přeneseně provádí. Schopnost projektového manažera na veškeré problémy reagovat tak, aby mohly být včas řešeny, bude pak záviset nejen na jeho schopnostech, rozsahu jeho vlastních pravomocí, schopnostech a ochotě dodavatele ku spolupráci, ale také na kvalitě a detailu klientova vlastního původního zadání projektu.

Co se týče ocenění rizik a jejich úměrného zohlednění v nabídce dodavatele, záleží nejen na správnosti pochopení a výkladu klientova zadání hlavním dodavatelem, ale zásadně také na samotné kvalitě zadání projektu ze strany klienta. To totiž pak v důsledku ovlivňuje cenu rizika (tzv. risk premium) $\checkmark$ nabídce dodavatele. Jak je v soutěžích projektů design and build obvyklé, nabídkové ceny nejsou vyžadovány $v$ podrobném rozpadu na jednotlivé položky, tzn ani ocenění jednotlivých rizik z nich nemusí být patrné. Při absenci dohody o sdílení rizik mezi klientem a dodavatelem $v$ představební fázi bude pak z pohledu klienta velmi obtížné snižit následně jednáním jejich cenu.

Absence takové dohody o sdílení rizik má za důsledek další problémy v prípadě, že si klient přeje provést změnu svého zadání $v$ průběhu realizace projektu, nebo $v$ prípadě, že je třeba vyhodnotit nároky či požadavky vyplývající z nastalého zpoždění a přerušení realizace. Výše zmíněná častá nepř́tomnost podrobného cenového rozpadu nabídky pak projektovému manažerovi, prípadně klientovi, působí značné potíže při následné snaze tyto nároky či požadavky cenově vyjádřit, včetně časového hlediska.

\section{Možné využití dodavatelských systémů $\mathrm{CM}$ a $\mathrm{CM}$ at Risk}

Dodavatelské systémy Construction Management (CM) a Construction Management at Risk (CMatR) jsou dobře využitelné $k$ aplikaci při časném zapojení dodavatele $(E C I)$. Důvodem je to, že jsou použité jak pro činnosti předrealizační fáze, tak pro umožnění plynulého a urychleného zahájení stavebních prací.

Systém CM je charakterizován časným určením řídícího dodavatele, který zahájí dodávky jednotlivých ucelených částí stavby (work packages), zatímco ostatní se teprve projektují. Jeho odpovědnost jako hlavního dodavatele je omezená při př́padném defaultu některého $z$ jeho subdodavatelů části stavby jen na částky skutečně vymožitelné [1].

Construction management at risk je podobný z hlediska možné rychlosti výstavby, ale jednotlivé části stavby si zadává klient smluvně přímo a CMatR dodavatel obdobně rídí stavbu jako hlavní dodavatel. Profesionální odpovědnost CMatR dodavatele je v podstatě v rovině konzultanta či projektanta.

Všechny tyto dodavatelské systémy nezahrnují $v$ předrealizační fázi implicitně povinnou spolupráci rídícího dodavatele (tzn v rámci $\mathrm{CM}$ ) nebo manažera ( $v$ rámci CMatR) s projektantem. Tato spolupráce musí být specificky dána kontraktem. Pro klienta je to zvlášt́ důležité vzhledem výše zmíněnému riziku ze selhání dodavatelů již zahájených ucelených částí stavby. Toto selhání může mít charakter např́iklad platební neschopnosti a následného úpadku. Při neexistenci typického generálního dodavatele je to pro klienta zvlášt obtižné, a proto musí spoléhat na CM nebo CMatR ve funkci hlavního dodavatele, který bude mít za úkol na dané selhání včas upozornit.

\section{Klasický model - DBB bez spolupráce s realizátorem}

Velký počet klientů se spokojí se zadáním stavební zakázky až po zpracování veškeré dokumentace, výkazu výměr a poměrně přesně stanovené předběžné či kontrolní ceny. Výsledkem výběrového řizení je vybraný dodavatel, který zaručuje většinou pevnou cenu stavby s relativně malým počtem změn $v$ průběhu realizace. $Z$ hlediska počtu změn je obvykle více změn při veřejných zakázkách, vzhledem $k$ tomu, že cena je většinou výsledkem soutěže s větším počtem účastníků. Tato cena je relativně nízká a neumožňuje dodavateli reagovat na jakákoliv rizika jinak než požadavkem na změnové financování. 
Hlavním problémem této metody, a to jak u soukromých či veřejných zakázek, je že projektantům a konzultantům klienta se tento systém líbí a umožňuje jim pohodlnou a málo kontrolovanou činnost podle vlastního vkusu a prání. Klientovi se při tom zdá, že až do okamžiku realizace má pod kontrolou design i rozpočet [2].

Tento model je ale charakteristický tím, že od dodavatele stavební části, který obvykle bývá nejzkušenějším účastníkem projektu, se vyžaduje při výběrovém řízení a při realizaci jen to, že je povinen realizovat stavbu zcela podle dokumentace. Jakékoliv změny či varianty na bázi value engineeringu nejsou většinou prípustné [7]. Hlavním rizikem pak bývá oportunismus generálního dodavatele, který viní projektanta a klienta z nekvalitní dokumentace a vyžaduje změny v termínech a ceně.

Současná teorie v oblasti dodavatelských systémů hovoří o selhání tradičního modelu založeném na předrealizačních činnostech bez spolupráce budoucího dodavatele a aplikace jeho know-how. Tento model je zásadně nekooperativní a redukuje každého účastníka projektu na zastánce jen vlastních zájmů. Tím se ztrácí existující synergie, která je zabudována v principu a metodách projektového řízení!

Podle literatury i současné praxe jakékoliv pokusy zahrnout budoucího dodavatele či několik budoucích dodavatelů do předrealizační fáze formou částečně placené součinnosti selhává. To je dáno základním uspořádáním dodavatelského systému DBB, kdy je vždy klient v konečné fázi sám odpovědný za veškeré vady a problémy projektové dokumentace [3]. Nicméně jednoduchost a přehlednost oddělení fází tradičního systému DBB představuje největší bariéru aplikace časného zapojení dodavatele $(\mathrm{ECI})$. To platí zejména pro veřejné zakázky, kde argument rovnosti všech účastníků nabídkového řízení přemáhá všechny potenciální výhody ECI.

\section{Překážky osobního / názorového charakteru}

Některé překážky využívání metody časného zapojení dodavatele a využíaání smluv o předvýstavbové fázi projektu můžeme charakterizovat jako záležitost předsudku [4], názoru či osobního postoje zúčastněných reprezentantů jednotlivých stran projektu nejen vůči metodě časného zapojení dodavatele, ale obecně vůči novým metodám či postupům vůbec.

Např́klad Bennett [5] zdůrazňuje mentalitu volného trhu, který může považovat i představu o spolupráci nebo dohody o společných zájmech jako byrokratickou nebo intervenční a tudíž nežádoucí. Dále pak také naznačuje, že ve Velké Británii jsou ve stavebnictví "hluboce zakořeněné strukturální důvody", které ji vedou $\mathrm{k}$ jednání pouze v rámci "krátkodobého výhledu". Takovýto přístup Ize však snad z lidského hlediska považovat obecně za přirozený a lze jej předpokládat na všech stavebních trzích celého světa.

Pomalý pokrok ve změně postojů jednotlivých účastníků těchto projektů by však jistě neměl porazit inovativní přístupy $k$ zadávání veřejných zakázek a řízení projektů. Osobní postoje budou pravděpodobně z největší části utvářeny na základě osobní zkušenosti, a tak Ize předpokládat, že s narůstajícím počtem úspěšně realizovaných projektů a z toho plynoucích dobrých zkušeností se budou tyto postoje vưči této nové metodě stále více nakloněny.

\section{Závěrem $\mathrm{k}$ překážkám ECI}

Závěrem Ize konstatovat, že jakékoliv formy využití značného know-how stavebních dodavatelů formou časného využití dodavatelů $(\mathrm{ECl})$ jsou ve většině zemí u veřejných zakázek neprůchodné a je možno je aplikovat jen formou vyšších dodavatelských systémů jako je DB nebo EPC/turnkey. Výjimkou je tedy stále jen Velká Británie, která programově již řadu let využívá $\mathrm{ECl}$ zejména u velkých projektů dopravní infrastruktury a dalších velkých veřejných projektů a může tedy ostatním zemím býti vzorem. 
Efekt z této formy veřejných zakázek je významný a projevuje se zejména $v$ oblasti kvality a nákladů životního cyklu (LCC) těchto staveb [6]. Překážkami využivání metody časného využití dodavatelů není tedy $v$ rámci veřejných zakázek pouze legislativa, která pojem $\mathrm{ECl}$ nezná, ale $v$ mnoha prípadech $\mathrm{i}$ neznalost a nedůvěra některých $z$ účastníků projektu $v$ ní. Tento stav je však $v$ zájmu efektivity vynakládání veřejných financí nutno co nejdřive změnit.

\section{Literatura}

[1] OBERLENDER, G. D.: Project management for engineering and construction, 2nd edition, McGraw-Hill, 2000.

[2] TOMEK, R.: User costs as one of main advantages of precast concrete application in highway construction, In: Building up Efficient and Sustainable Transport Infrastructure 2017 (BESTInfra2017). Bristol: IOP Publishing Ltd, 2017. IOP Conference Series: Materials Science and Engineering. vol. 236. ISSN 1757-8981, Scopus: 2-s2.0-85034053717.

[3] WALKER, D. (Editor): Procurement Strategies : A Relationship-based Approach. Chichester, GBR: John Wiley \& Sons, Ltd, 2008.

[4] NOVÁKOVÁ, V.; AHMED, S.; VITÁSEK, S.: Problems of technical education and lack of students at Czech technical universities, In: Engineering for Rural Development, Proceedings of 17th International Scientific Conference. Jelgava: Latvia University of Agriculture, 2018. p. 635-639. ISSN 1691-5976, Scopus: 2-s2.085048950239.

[5] BENNET, J. (2000) Construction: The Third Way. Butterworths-Heinemann, Oxford.

[6] SCHNEIDEROVÁ HERALOVÁ, R.: Life cycle costing as an important contribution to feasibility study in construction projects, In: Procedia Engineering. Amsterdam: Elsevier B.V., 2017. p. 565-570. vol. 196. ISSN 1877-7058, Scopus: 2-s2.0-85030456335.

[7] SCHNEIDEROVÁ HERALOVÁ, R.: Possibility of Using Value Engineering in Highway Projects, In: Procedia Engineering. Amsterdam: Elsevier B.V., 2016. pp. 362-367. vol. 164. ISSN 1877-7058. Scopus: 2-s2.085006999575. 